DOI: $10.2478 /$ ausfm-2020-0007

\title{
Conflict Types in Hungarian Film History
}

\author{
Balázs Varga \\ Eötvös Loránd University (Budapest, Hungary) \\ E-mail: vargabalazsbalazs@gmail.com
}

\begin{abstract}
The article introduces the collective research project entitled The Social History of Hungarian Cinema, 1931-2015, executed by the staff of Film Studies Department Eötvös Loránd University. This data-driven research aims to examine how and why Hungarian films have changed over time. Using the case study of conflict types in the plots of Hungarian films this study discusses the methodological problems of longitudinal explanations of change in Hungarian film history (periodization and dividing film between genre-based film and auteur films/art cinema). Based on the analysis of statistics and trends, the study presents the most important types of conflict in Hungarian film history. With respect to the political turning points and the periodization of Hungarian film history, the article states that each of the three broad periods (1931-1944, 1945-1989, 1990-2015) is characterized by its own distinctive set of prominent conflict types. The pre-1945 era is characterized by a massive number of love conflicts, the socialist period by the highest rate of political conflicts (and the lowest rates of love and crime conflicts), and the post-socialist period by a high rate of crime and generational conflicts. Furthermore, by analysing the connections between conflict types and genres, the study reveals recurring patterns and trends of shorter periods: it shows how the range of conflicts narrowed considerably over the 1970s and discusses the extent to which this is related to the dominance of auteur films in the era. ${ }^{1}$
\end{abstract}

Keywords: Hungarian cinema, conflict types, statistical analysis, genre films and auteur films, periodization.

The history of film history writing is a long succession of various paradigms and turns, and is usually arranged around certain binary opposites that are familiar to the fields of humanities - such as text/context, empirical/conceptual, close reading/ distant reading, data-driven/hypothesis-driven. The connections between - and dynamics and prevalence of - formal, stylistic, generic norms and social-cultural

1 This paper was supported by the Hungarian National Research, Development and Innovation Office (number of Agreement: 116708). 
contexts is the subject of endless debate, questioning whether we should focus on the descriptions, explanations and the understanding of formal norms or on the determinative forces of social and cultural contexts in the shaping of films. David Bordwell, discussing the methods of historical poetics, voted for the first option and emphasized that film historians should consider two broad questions. " 1 . What are the principles according to which films are constructed and by means of which they achieve particular effects? 2. How and why have these principles arisen and changed in particular empirical circumstances?” (Bordwell 1989, 371.) However, Bordwell never denied the formative force of exogenous factors as he stressed that "it is perfectly possible to find that the formal phenomena we're trying to explain proceed from cultural, institutional, biographical, or other sorts of causes” (Bordwell 1997, 5).

In a special issue of Cinema Journal in 2004, which discusses the past and present challenges of film history writing and comments on Bordwell's thoughts on historical poetics, Lee Grieveson formulated the open-ended question of texts and contexts in the following way. "What are the possibilities for a cultural history of cinema that takes the tenets and reservations of historical poetics seriously? Likewise, what are the possibilities for a historical poetics that takes seriously the aims and possibilities of a cultural history of cinema?" (Grieveson 2004, 122.) In our collective research project entitled The Social History of Hungarian Cinema we have faced similar questions: how can we take seriously these different forces of historical poetics and social-cultural history? Our project aims to examine how and why Hungarian films have changed over time. We explore the evolution and transformation of motifs, forms, patterns, genres, and topics over time, and seek the possible causes and explanations of these changes. Thus, the key questions are: how do we recognize a change in films (what is changing over time), how do we identify and perceive the collection of thematic, generic or stylistic patterns as being indicative and significant (which of these changes and patterns reveal an important trend or connection, and hence calls for explanation), and then how do we provide the (historical) explanation for that change? The basic explanatory factors (with which we would like to explain historical change) are: historicalpolitical influences, social factors, institutional-technological effects, cultural causes, and local and international trends within filmmaking culture. We do not want to engage in the debate on which endogenous forces, formal components or social-cultural factors take precedence in the shaping of Hungarian films. We believe both endogenous and exogenous factors have their own impact, and these effects change and combine over time. Our project examines well-known trends 
and seeks novel patterns of change in Hungarian films, and assumes that there are different factors that can cause and explain these changes. Our assumption is that in different periods and in different situations these potential factors are activated in different ways, in other words, some of them will be said to have a stronger (and others to have a weaker) influence when we explain the forces behind the change in the patterns of Hungarian films.

This article will use the case study of conflict types in the plots of Hungarian films made between 1931 and 2015 to show the methodological problems of longitudinal explanations of change in Hungarian film history. Of the questions of detecting change over time and the explanation of the motivating factors of change, the article will focus on the former, and will discuss what the analysis of conflict types might reveal about Hungarian film history and about the social functioning of cinema. Following an overview of the problems of Hungarian film historiography and the examination of questions of longitudinal analysis (specifically periodization and dividing film between genre-based film and art cinema), the article will introduce the basic methodology of the research and show what novel trends and patterns the analysis of conflict types reveals.

\section{Historiography of Hungarian Film History}

An important aim of the research is to describe the changes in Hungarian film history according to homogenous and consistent criteria. Existing texts and longitudinal discussions on the entire history of Hungarian cinema generally lack methodological and theoretical reflection, and review Hungarian film history in chronological order with a focus on the most important trends and prominent and iconic films of the given era (Burns 1996; Balogh, Gyürey and Honffy 2004; Cunningham 2004; Gelencsér 2017). This is presumably not independent of the fact that their main target audience is the cultural public that is interested in Hungarian and Eastern European cinema (such is the case with the English-language volumes), or that they provide a kind of textbook-like introductory narrative to Hungarian film history. ${ }^{2}$

Academic texts on Hungarian film history have applied heterogeneous considerations, and have not consistently examined the whole continuum of film history. These studies usually focused only on a given period, and their considerations were diverse. Gyöngyi Balogh and Jenő Király's monumental

2 Gábor Gelencsér's recent book entitled Hungarian Film 1.0 even highlights this aspect with its title, and stresses in the introduction that its target audience is the teenager and youth generation (Gelencsér 2017). 
work on early and mid-1930s Hungarian filmmaking culture employed detailed textual and genre-based analysis, providing a thorough investigation of the films as products of Hungarian cultural history and mentality (Balogh and Király 2000). Tibor Sándor and Márk Záhonyi-Ábel conducted extensive archival research to explore the political contexts and the influence of regulation on the Hungarian cinema of the late 1930s and early 1940s (Sándor 1997; Záhonyi-Ábel 2019). Gábor Gergely and David Frey examined the political discourses and institutional contexts of the 1930s' and early 1940s' Hungarian filmmaking culture (Gergely 2017; Frey 2018). Gábor Szilágyi’s books provided an analysis of the institutional context and the production history of Hungarian films from the early and mid-1950s (Szilágyi 1992, 1994). Gábor Gelencsér's book on the 1970s analysed the main artistic trends of the decade (Gelencsér 2002). My book focused on the post-socialist institutional transformation of Hungarian film industry (Varga 2016a). These works reflect on a limited scope (aesthetic, institutional, political, etc.), and therefore cannot portray the period comprehensively. A further limitation of existing research on specific periods is that it does not consider how the preceding years and trends influenced these eras in the form of institutional, structural and socio-cultural traditions (and even less attention is directed to the question of how each period influenced the one following it). Furthermore, analyses with a limited scope cannot adequately portray how different areas and forces of culture and Hungarian cinema's ecosystem interact with each other. Stylistic analyses cannot accommodate questions on the cultural context at a specific time, and production histories do not consider how an institutional structure impacts the various types of films produced.

Therefore, our research project attempts to fill the gap outlined above by analysing Hungarian film history not through its separate features but as a complex and interconnected phenomenon. This project is not concerned with selected periods but rather with the complete history of Hungarian sound film, using a methodology that allows for the investigation of trends and traditions over a long period - a consideration that is missing from existing literature.

\section{Periodization in Question}

The decision to perform a longitudinal analysis of Hungarian film history brings with it the challenges of periodization, and in particular the questions of discontinuities and ruptures. It is not necessarily our goal to revise the dominant narratives and existing periodizations of Hungarian film history, rather to understand whether the patterns emerging from our data-driven research confirm or disprove the temporal 
divisions and the periodization of previous studies. We are aware that periodization is already a contentious and much debated point in the field of historical studies and humanities (for example contemporary literary history/theory). It has also been more than fifty years since Michel Foucault drew attention to the problematic nature, and the controlling and consolidating power of periodization. Yet, periodization is still with us. The tendency toward demarcations and periodization might be understood to be an underlying human impulse: "we describe the world as changing in particular structured ways not because it actually always does so - though sometimes it does! - but because a series of biases toward change at a certain scale are built into our most fundamental models for understanding culture" (Hayot 2020, 203). An important argument in favour of periodization is that it makes differences apparent and helps to establish the context of a text. Although terms (and styles, accordingly) that are used to describe periods are often relative and artificial, they might be useful for comparison, to help analyse contrasting trends and styles (Brown 2001). Contrasts, conflicts and ruptures are inevitable but productive outcomes of periodization. "Given this background of how we measure change in the past, we must remind ourselves that historians generally see the past as both continuous and discontinuous. Stringing together facts, in what often appears to be a functionally deterministic way, historians draw a smooth line through the past. Both the facts and the continuity are, we now realize, constructed. We construct what is a fact and recognize that we could have emphasized other ones. And we impose continuity upon those we have selected. Equally important, however, is the recognition of ruptures in history.” (Mazlish 2011, 32.)

In the following, I will discuss two crucial aspects of studying Hungarian film history as a complex, long-term social-cultural phenomenon: ruptures and periodization as markers of dramatic political changes, and the question of the division of Hungarian cinema corpus between mainstream-commercial genre films and auteur-art films.

\section{Ruptures in Eastern European Film History}

The general issues of periodization and of ruptures will be especially relevant if we turn to the filmmaking culture of the Eastern (Central) European region. In his examination of Polish film history, Marek Haltof begins with the parallels between, and the common periodization of political and film history. "It is feasible to distinguish films made in the Polish territories during the absence of the Polish state (before 1918), the cinema of interwar Poland (1918-1939), the cinema of 
communist Poland (1945-1989), and the films made after the return of democracy in 1989." (Haltof 2018, 2.) However, the relationship between these periods and their place in the film history narrative is at least as interesting.

Marcin Adamczak, discussing the trends of transformation of post-socialist Polish filmmaking culture, emphasized the problem of the disproportionate portrayal of different periods in Polish film-history books. "Polish cinematic output of the postwar communist period tends to be valorized and nostalgized. In contrast to those of the Second and Third Republics, such films are very much a part of Polish film culture thanks to continued popular and academic interest. Exemplifying this situation is the book The History of Polish Cinema: Masters, Films and Contexts, in which Tadeusz Lubelski devotes only 67 pages to the cinema of the Second Republic, and just 79 to the Third Republic. These numbers stand in marked contrast to the 374 pages he allocates to the cinema of the People's Republic.” (Adamczak 2012, 45.) In Adamczak's interpretation, the biased discussion emphasizes the value-oriented narrative of Polish filmmaking culture: "these periods function as mere bookends to the main body of enquiry. However, it should be stressed that, at the time of writing, the combined duration of the Second Republic (21 years) and Third Republic (23 years) is equal to that of the 44-year-long People's Republic. Estimates indicate that the number of Polish films produced in the two periods is roughly equal to that of the much-vaunted People's Republic. The disproportionate attention paid to the cinema of the People's Republic can only partly be explained as a product of the difficulties involved in accessing surviving Second Republic films or of the time-lag that often characterizes Film Studies' embracing of contemporary cinema” (Adamczak 2012, 46).

The same political-temporal segmentation is used to portray Czech film history. "During its hundred-year-long history, the Czech film survived five different social systems. Its origins (the first films on the Czech soil were presented by Jan Křřženecký in 1898) are rooted in the era of the Austro-Hungarian Empire. After the First World War, it continued its development in a free and democratic Czechoslovak Republic which was after two decades destroyed by the Nazi Germany. A fundamental systemic change occurred in 1945 when the Czechoslovak film was nationalized i.e., that the state (and after 1948 the Communist establishment) completely controlled all film activities in the entire country. (1) After the demise of the Communist dictatorship in 1989, a democratic regime was reestablished and with it the market economy; the film production was privatized and returned to the hands of private producers and distributors. (2) This dependency of the Czech film production on external conditions which were preventing the natural, continuous and intrinsic development of the film art was intensified by a specifically Czech cultural tradition 
which often preferred the social and educational function of art over its aesthetic function.” (Voráč 1997.) Further examples could, of course, be added, but perhaps, for these purposes, it is sufficient just to mention German film history, which is also "structured around the historical events, including two world wars and five regime changes, which mark German cinema as a site of crises, ruptures, and antagonisms, but also of unexpected influences, affinities, and continuities" (Hake 2002, 1).

Two dates intuitively determine how to think about periodization and continuity regarding Eastern European cinema: 1945 and 1989. In other words, the years of state socialism (as years of shared political and cultural experience of the countries of the region) clearly articulate, and also organize the periodization of both political and film history through ruptures and/or continuity. Subsequently, historical overviews of the filmmaking cultures of the region are organized (in a way that is almost taken for granted) into a three-part structure: the pre-socialist, the socialist, and the post-socialist period.

It is also clear that while 1945 and 1989 stand out in the film history of Eastern European countries, there are significant differences between national film cultures and political histories in terms of what changes took place and how. For Czech, Slovak and Polish political and film history, the years 1938 and 1939 represent times of dramatic ruptures and change, although in different ways. Polish filmmaking almost totally came to a halt during German and Soviet occupation (1939-1945). Only a few films were made, and many of the filmmakers emigrated after the invasion (Haltof 2018). Similarly, there were no feature films made in Slovakia during the German occupation (Votruba 2005), and the annexation of Czechoslovakia also dramatically impacted Czech film production. However, due to its high technological equipment and standards, Prague became an important centre of German film production (Johnson 2012). Besides German productions, some Czech feature films were also produced, but the domestic production numbers dropped dramatically (Klimes 2007). Most of the Czech films that were made were filmed in the smaller and less well-equipped studios. Because the Czech film industry was able to survive the devastation of the war relatively unscathed, its resumption in 1945 was also smoother (Hendrykowska 1999).

1989 was, undoubtedly, also a turning point for the region's filmmaking cultures. The transition for both Polish and Hungarian film production was more continuous. For Czech film, privatization and generational change were the major challenges, while the filmmaking culture of Slovakia, which became independent in 1993, as Katarína Mišíková wrote, was on the path of "eternal revival” (Mišíková 2016). Ruptures and continuities are fascinating topics for the discussion of the late-Soviet 
period, and the cinema of perestroika (Beumers and Zvonkine 2018). Furthermore, the position and investigation of East German filmmaking culture, and the question of how it is situated, embedded and contextualized within German film history, are also challenging. Did East German filmmaking culture start from nothing in 1949, to be dispersed and terminated in 1990 with the reunification of Germany? What can German cinema and film historians of German cinema do with the legacy of the East German filmmaking culture? (Heiduschke 2013; Byg 2002.)

Therefore, we can agree with Sabine Hake that "the notion of national cinema as a category of difference and contestation also complicates the understanding of film history as a linear narrative with distinct periods and movements, continuities and ruptures, and cycles of rise and decline" (Hake 2002, 6).

\section{Auteur Films and Old/New Divisions of Hungarian Film History}

Besides the challenges of periodization, there is another intricate division of the Hungarian film corpus that must be tackled, namely the duality of, and the distinction between genre-based films and art/auteur films. This topic is closely related to the problem of periodization, since Hungarian film history is usually described as having a pre-1945 period dominated by popular filmmaking and genre films, while after 1945 (and especially from the 1960s) auteur films and art cinema assumed the dominant position. The explanatory power of this binary framework (not to mention its theoretical clarity) is limited, for example, by the fact that the post-socialist era is difficult to place within this duality (as after 1989 we can see relative balance between commercial and art cinema - with a continuous decline in the proportion of the latter, and a hybridization of the strategies of mainstreampopular and authorial filmmaking). Yet, research that seeks to examine Hungarian film history in a unified way must respond to the problem of the duality of genreoriented commercial cinema and art cinema/auteur films. So far, I have used the terms art and auteur in parallel, which is not by accident. Hungarian film critics and film historians generally do not distinguish between the two concepts and use them interchangeably, as if they were synonyms. The fundamental thesis of auteur theory, namely that authorship and genre-based filmmaking are not incompatible with each other, has little weight in common interpretations of Hungarian film history: critics and historians usually use the term auteur to mean the opposite to commercial (and designate as auteurs those directors who are the scriptwriters of their own films). Yet, we would not be more well-equipped if we were to consider many of the 
leading directors of pre-1945 popular filmmaking culture as auteurs (although it is a relevant and resourceful way for the reinvestigation of the first decade of Hungarian sound film era). It seems a better solution to describe the aforementioned (pre-war and post-war) divisions within the duality of genre-based commercial filmmaking and art cinema, which is not easily characterized by (the direct and open use of) genres. Setting aside the problems related to the definition and the divergent use of the auteur film category, we immediately run into another terminological problem, namely when describing art film and art cinema. Art cinema, if it is possible, is an even broader and less definable category than auteur film. Theoretical discussions regarding the term usually underline its elusiveness, heterogeneity and impurity (Andrews 2013; Galt and Schoonover 2010), and highlight the value-oriented aspects of the category (which serves as a basis to contrast art cinema with Hollywood and mainstream/popular filmmaking). Our research, in order to analyse the broader trends in Hungarian film history, relies on those theories that describe art cinema as an institution and as a mode of film practice (Bordwell 1979; Neale 1981). Thus, we consider art cinema to be more complex than a set of formal and narrative characteristics (such as realism, opacity, open textual qualities and authorial vision) and focus on the cultural, social and institutional aspects of this type of filmmaking. Yet, we claim that there are distinct textual specificities to art films that allow us not only to distinguish them from genre-based films, but to place both (i.e. genre films and art films) within a broader and unified system of categories. Although art films have important thematic features (the theme of the film is often the expression of the author's own vision [Kovács 2018]), they cannot be thematically delineated - as opposed to many genres such as western or war film. However, we can point to another very important genre, namely comedy, for which it can also be said that it cannot be delineated thematically. Besides their significant narrative and dramaturgical features, art films cannot be narrowed down to these distinguishing attributes, nor to the differences in their impact on the viewer (they primarily target an intellectual effect instead of the emotional impact expected of genre films [Kovács 2018]). Finally, an art (auteur) film "typically has a traditional genre component, and often more than one at a time, but its main feature is that it is not genre specific, i.e. it doesn't have thematic and dramaturgical features that make it function as a specific genre in a broad sense. One sign of this is that it has subgenres like the essay film, the mental journey film, or the intellectual melodrama” (Kovács 2018). Thus, in our database we have a category for the broad, introductory description of the films in which we characterize them based on their leading genre - and in this category we include auteur film alongside the main genres. All this, then, in 
our interpretation, is not a category mistake but an effort (supported by the above arguments) to describe and typify Hungarian films in a unified way. Furthermore, we use the term auteur (and not art film) as a category precisely because it fits better with the Hungarian tradition of film criticism. Finally, given the importance of genre bending and hybridization, and so as not to characterize a film by a single category/term, another category of subgenres is also included in the database. Here, in addition to the main genres, the list also includes the art/auteur film subgenres mentioned by Kovács (mental journey, docu-fiction, intellectual melodrama, essay film). This is again an eclectic list of (sub)categories, and we do not claim that these subgenres of art/auteur films are typical and valid in all cultural contexts. This list is based on our preliminary hypothesis and knowledge regarding Hungarian cinema: there are categories which might be important within the context of Hungarian (Eastern European) film history, such as intellectual melodrama, but there are some, such as mental journey, that are broader - and therefore likely to be a more internationally recognized subcategory of auteur films.

Regarding the distribution of main genres (including auteur films) in Hungarian film history, we can see in the graph shown in Figure 1 the impact and importance of auteur films within Hungarian filmmaking culture. According to our database, the first auteur film is Miklós Jancsó's Cantata (Oldás és kötés), from 1963. From that year on, there is an ongoing growth in the number of auteur films. In the 1960s there is balance amongst the leading genres (comedy, drama, historical and crime films) and auteur films, but the next decade, the 1970s brings the (almost) total dominance of auteur films. There are comedies and historical films, but the majority of the films belong to the eclectic group of auteur films (art cinema). Thus, contrary to the common perception that the 1960s were the golden era of auteur cinema (which is naturally relevant in terms of the local and international breakthrough of auteur films in this period), from the perspective of (statistical) balance within Hungarian filmmaking culture, the 1970s were the peak period. This trend continued in the 1980s, although the genre spectrum of Hungarian cinema became more varied in this period. Following the political changes, the dominance of auteur films gave way (again) to a much more balanced, more heterogeneous profile and genre pattern - especially from the mid-2000s (Varga 2016b).

In his study, Kovács connects the changes and variations of the dominant genres in Hungarian film history with the changes in the industry and financing systems. He states that in addition to comedy, the other leading genre in Hungarian film history is melodrama (both its more classical genre-form and the art cinema/auteur film version), where it is interesting that in Hungarian filmmaking culture it is not 
the dichotomy of joyous and serious genres but that of the cheerful and sad genres that suggests hopelessness, and this dichotomy reigns not only before WWII but also during the socialist and post-socialist period (Kovács 2018).

\section{Film History and Statistical Analysis}

While big data and statistical analyses have fundamentally influenced and inspired the methodology and the scope of approaches to screen studies, there are some areas that are more likely to be examined - while others are less so. Stylistic analysis (Salt 2006; Heftberger 2019) and the examination of cinema audiences and the moviegoing public (Maltby, Biltereyst and Meers 2011) belong to the first, and the discussion of long-term genre trends and narrative patterns belong to the second. However, there are some notable studies which focused on the analyses of longterm trends of genre change and (narrative or content) patterns of a given (national) film corpus.

Claude Rubinson and John Mueller's study examined how genres are combined in mainstream American films, and how the popularity of particular genre combinations changed between 1946 and 2013 (Rubinson and Mueller 2016). By distinguishing between "contextual genres” (which identify a film's subject matter) and "affective genres" (which identify a film's intent), they found marked differences between the post-war and blockbuster (post-1970s) eras of Hollywood film industry.

Another interesting study was Jessica Allen, Sonia Livingstone and Robert Reiner's piece on the changing images of crime in British post-war cinema (Allen, Livingstone and Reiner 1998). Their investigation employed both a quantitative and a qualitative content analysis of popular crime films in Britain released between 1945 and 1991. Despite common beliefs, they found no overall increase in the number of crime films.

Finally, the UK Film Council commissioned a report examining British films with respect to the portrayal of Britishness, covering the period 1946 to 2006 (UK Film Council 2006). The total corpus of films they examined and considered to be British consisted of 4,655 films. For the purposes of detailed analysis they created two samples. The first group, called intuitive, included the films that, according to the critical consensus, were the most influential. The second group comprised a list of films that were randomly selected from the whole film corpus, to serve as a control for the intuitive group. Both groups consisted of 200 titles. In addition to disproving some commonly held ideas (such as British films tend to turn to the past), a very interesting aspect of the study was its investigation of the portrayal of 
Britishness through British values. These values were compiled based on various public indications, with the list containing such values as tolerance, fair play, decency, honesty, reticence, understated patriotism, and gallantry or self-sacrifice. The main (but not really surprising) finding of the report was that the intuitive films' portrayal was more satirical and challenging towards these values, and the random corpus represented a more mainstream (i.e. more reinforcing) image and attitude towards them. Furthermore, the report contained 30 case studies which identified eight themes that are characteristic of British cinema. It is a varied and eclectic list, comprising the protagonist-types and thematic motifs of small-time criminals; comedies about eccentric characters or ordinary people (dreamers) in extraordinary situations; the ambivalent portrayal of heroism and victory; the trend of popular films to show fantastic and heroic characters; the openness and tendency to portray the lives of youths; period films with aspirations to convey moral lessons to a contemporary audience; and the discussion of controversial sexual and gender issues.

The approach taken by our research group differs from the projects described above. We do not examine the transformation of a particular genre or group of genres, we are not directly interested in social representation, and we do not analyse the portrayal of values or attitudes.

Our research is aimed at genres, plot types, milieus and locations, the socioeconomic background of the protagonists, character development, and the question of when the films' plot takes place. What we are looking for is the repeated occurrence of patterns which reinforce or reframe our understanding of the main trends and trajectories of Hungarian film history. Additionally, we are looking for the possible explanations for these trends and patterns: we would like to analyse the predominant factors behind these patterns. To put it differently: we are looking for the social, cultural, endogenous and exogenous explanations of change over time in the patterns of Hungarian filmmaking culture.

\section{Methodology}

Our research is a data-driven project which uses a database to register relevant features and characteristics of Hungarian films (genre, subgenre, plot time, conflict type, location, milieu, the social background of the protagonists, character development, etc.) and seeks to explain the patterns and the changes over time. The corpus of the research consists of all Hungarian sound (feature) films made between 1931 and 2015 - a group that can be analysed with a coherent approach. However, the database forms only the foundation of the research. Statistical analysis is used 
to perform most of the queries (e.g. the number and proportion of Hungarian feature films with female protagonists in film history, combined with other aspects such as genre, conflict, social status, or just how the given film portrays the story of social mobility or social and financial downfall). Why and for what is statistical analysis good? Garin and Elduque asked this question in the following way. "Are those quantitative efforts expanding traditional methods of historiography with new research tools? Or do they reinforce fully institutionalized parameters, and therefore point us to the same old story?" (Garin and Elduque 2016, 884.) On the one hand, we are using the database to confirm previous assumptions regarding the trends and dynamics of Hungarian film history, and on the other we are looking for patterns, topics and problems that have not been studied before, and that can reveal new connections within Hungarian filmmaking culture. The database can be queried in every possible way, but obviously not all queries, reports and graphs will be interesting and revealing. Some of them will be insignificant and others will confirm well-known trends. We are therefore looking for queries that show unexpected patterns and connections. These results might call for fresh answers and help us to work on new and complex interpretations - mobilizing different types of endogenous and exogenous explanations. In this sense, we can say that our research is not based on pre-defined questions, but seeks out novel and unexpected patterns.

Through statistical analysis we look for patterns, variations and combinations that have not been noticed and analysed in previous studies. As Boyd and Crawford point out: "Big Data is notable not because of its size, but because of its relationality to other data" $(2011,1)$. Thus, what we are seeking is new and relevant connections, conjunctions and patterns in Hungarian film history, and we are trying to allow for the possibility of "distant reading" which, in Franco Moretti's words, might allow us "to focus on units that are much smaller or much larger than the text: devices, themes, tropes - or genres and systems” (Moretti 2013, 48). Working with a database and with queries means that there is a series of transformations: first, we are coding cinematic texts into database records. Then (via queries), converting these records into numbers. This is followed by another shift - the transformation of these numbers into abstract models of visualization: graphs. The aim of these transformations is that they can be used (similarly to maps) as analytical tools to "dissect the text in an unusual way, bringing to light relations that would otherwise remain hidden” (Moretti 1998, 3).

However, the visuals and the revealing power of graphs, tables and diagrams should not go unquestioned. As Rachel Serlen argued, criticizing Moretti: "the problem is always quantitative; whether it be the slope of the line, the dots on the 
map, or the branches in the tree; but the explanation of that problem comes from another realm of knowledge. The external aspect of explanation, which interpretation lacks, is what explains the data, what causes the data to be what they are. The graph itself can never answer the graph. What can answer the graph is form" (Serlen 2010, 220). Indeed, the hypothesis of our research project is that there are other significant aspects of explanation besides the form - namely cultural factors, and institutional and political causes. These factors combined, along with their complex interplay, have shaped Hungarian filmmaking culture and the world of Hungarian films.

\section{Periodization and Trajectories of Hungarian Film History}

Having considered the questions of methodology and historiography, and before we get into the specifics of genres, conflict and plot types, it will be important to briefly examine the corpus and explore the broader trends of Hungarian film production. This will then lead us to the general periodization of the years between the early 1930s and the 2010s. Figure 2 shows the number of Hungarian films made between 1931 and 2015, i.e. the more than fifteen hundred films form the corpus of our research. The distribution over time and peaks reveal important specificities of Hungarian film history. Most obviously, we see major fluctuations in the number of films made per year. The yearly average is 18 films, but the gap between the peak year (51 films were made in 1943) and the lowest point (only one film was produced in 1946) is dramatic, even if it is clear that the end of WWII resulted in a "zero year" (and was followed by a restart). Since the early 1930s, when Hungarian sound film production began, there has been a steady rise in the number of films produced, which peaked with the boom of the wartime years (especially 1942-43, when the boycott of American films opened South-Eastern distribution markets for Hungarian films [Frey 2018]). After 1945 and the restart of the industry, annual numbers began to rise again slowly, and film production got a strong boost in the mid-1950s. After that, and following the decentralization of the industry in the early 1960s, the annual Hungarian film output stabilized (Varga 2012). Since then, and essentially up until today, an average of 20-25 Hungarian films are made per year - although there have been major fluctuations in the recent years: in the mid-2000s, in connection with the 50th anniversary of the 1956 revolution, a lot of films were produced (with the financial help of a special state fund), and at the beginning of the 2010s, in the years of the transformation of the Hungarian film financing system, the number of films fell sharply (at that time state funding almost stopped for two-three years) (Varga 
2016a). It can also be seen that there are definite political-institutional reasons behind the annual number of films and their fluctuations - where the change in the number of Hungarian films produced is principally influenced by external forces rather than endogenous factors within the local filmmaking culture.

Now, if we take the aforementioned unequivocal political demarcation points $(1945,1989)$ and segment the graph with them, the nature of the three resulting periods, and their film output, is very different. Between 1931 and 1944, during a dramatic fourteen years, 354 films were produced ( $23 \%$ of the corpus). The more than four decades of the socialist era, between 1945 and 1989, brought 701 films (46\%). And finally, after 1989, in the post-socialist era, 461 films were produced $(31 \%)$. Considering the length of the periods and the number of films produced, there does not seem to be a dramatic difference between them: as in each there was an average of 15-25 films made per year. Yet, if we look at the dynamics within each period, the differences become more pronounced and interesting. Between 1931 and 1944 we see a rapid increase and boom. Between 1945 and 1989, after a slow increase, a steady annual output sets in. And after 1989, there is no consistent trend - instead, there are large fluctuations in the number of films made each year. These differences can actually be readily understood through the distinguishing features of the three periods: the market-oriented commercial film production between 1931 and 1944, where growing demand resulted in increasing production, followed by four decades of socialist film production and its state-controlled, planned-economy logic, which resulted in a balanced and stable output. And ultimately, after 1989, the post-socialist period that was characterized by an uncertain, hybrid ecosystem and environment in which neither market demand nor state objectives were dominant and predictable. In the following, by examining conflict types, we will review the trends, ruptures and continuities of Hungarian film history with special regard for the question of how these trends are related to the crucial political boundaries of 1945 and 1989.

\section{Why Are Conflicts Important?}

So far, we have discussed the problems associated with assigning critical divisions to Hungarian filmmaking culture and film history - namely periodization and the distinction between, and duality of genre and auteur films. As we have seen, our solution to the latter problem was to position auteur (art) films as an alternative to genre film groupings within the same category in the database. Although we believe this to be a helpful approach, the examination of other general thematic aspects of Hungarian films is needed as well. 
In order to be able to obtain information about the multi-segmented, diverse and multifaceted Hungarian film history, it was important to use categories that provide unified queries on thematic-content aspects. With this in mind, the notion of conflict offered the most powerful means of categorization to expand the range of content and thematic queries for the database.

Although conflict is a keyword of narrative analysis and scriptwriting, theoretical discussions on conflict are more common in literary theory than in film theory. Subsequently, we are unable to build on a tradition of discussion on conflict types in film studies. Instead, the list of conflicts that we used in our research reflects our hypothesis and our understanding of the specificities of Hungarian film history.

What is a conflict? How can we define it? Conflict is a core characteristic of a narrative which is aligned to both action and character (and, if we define action as a product of the relationship between characters, then the two are inextricably linked). Thus, it does not only underpin the thematic category, describing the topic of the given film (what it is about), but also has relevance in terms of its nature and character. Conflict arises through opposition between two or more actors/actions, hence it represents the opposition of wills and intentions. So, if we define conflict as opposition - the conflict of values and interests - the next question is how these conflicts manifest themselves. By our definition, it does so in characters and actions. Conflict thus creates a connection between actors and actions, and is usually related to the theme of the film. Furthermore, every film has some kind of conflict - be it genre film or auteur film.

What makes conflicts particularly important in the study of Hungarian film history is the fact that the listing and analysis of conflicts can reveal the variations of a critical feature, namely the relationship between the individual and the community, the private and the public. Thus, when compiling the list of conflicts, an important consideration was to obtain relevant information for the classification of these features. In our list, conflicts describe the thematic scope of the film, with special regard to the relationship between individuals and larger groups of society. In our research we distinguished between, and used, the following conflict types: moral, private life, love, workplace, political, gender, generational, class, crime, $\mathrm{racial} /$ national, religion, fake identity, sport/leisure. This is indeed a heterogeneous list. It should be noted that this reflects our own hypothesis and understanding of the specificities of Hungarian film history, and therefore enables us to focus on the various dimensions and aspects of the relationship between individuals and community, private and public values. Thus, many of the conflict types we used might be applied to these dimensions. Moral conflicts are usually used to portray 
the conflicting perspectives of individuals. Love conflicts, apart from being one of the more common topics and plot types, focus on the story and conflicts of the romantic couple (thus, the focus here is still on the individuals). Conflicts of private life, in our definition, cover all types of conflicts which are beyond those of romantic love (that is not the formation and fulfilment of love [i.e. marriage, parent-child, husband-wife]). Conflicts within the family are usually coded as conflicts of private life, however, parent-daughter/son conflicts might be coded both as generational and/or private - depending on the focus of the given story.

Besides those conflicts that focus on individuals (e.g. romantic couples), we can isolate a different group of conflicts that focus more on the relationships within a group of people, or the conflicts between individuals and smaller groups (be it a family or workplace). Additionally, there are conflict types which usually mark conflicts or reflect divisions between individuals and the society: from political conflicts or crime conflicts (a special type of conflict, linked to the norms of society) to more general conflicts of generation, gender, class, religion - and also racial/ national conflicts, which are usually interpreted at the general level between communities and nations. Finally, we incorporated special, thematically unique conflicts as well, such as the conflict of fake identity (disguise, recognition) ${ }^{3}$ and conflicts regarding the fields of sport or leisure time.

Why and how is conflict different to genre? Certain conflicts we use can occur in different genres (e.g. religious or generational conflict). As some of the genres are defined thematically, there is some overlap (especially: crime conflict and crime films), however, there are certain types of conflicts which are to be found in almost every genre, such as romance. Similarly, private conflicts or workplace or moral conflicts are not limited to a certain genre. To conclude, conflicts are potentially very useful in at least three different ways: 1) they provide a broad thematic category which is applicable throughout the entire time span; 2) they transcend the genre and auteur film divide; 3) they transcend the demarcations of political periods $(1945,1989)$.

3 By this term we mean when one or more characters pretend to be different to whom the people around them think they are, or, because of misunderstandings, coincidences, etc. they look different to their normal appearance. Stories of disguise, makeup, camouflage, misunderstanding and deception appear in different variations and genres, but are equally found in spy films (deceptive, false identity), adventure films (outlaw heroes hiding from authorities), comedies based on misunderstanding and auteur films (stories of renegotiating and discussing identity). 


\section{Conflict Types in Hungarian Film History}

After this brief introduction to the discussion of the conflict types used within our research framework, we can now examine the distribution of conflicts recorded in our database. The following list shows the total number of conflicts in the films and the total number of different conflict types in order:

\begin{tabular}{lc}
\hline films between 1931-2015 & $\mathbf{1 5 1 6}$ \\
\hline total number of conflicts in the films & $\mathbf{4 1 6 6}$ \\
\hline love conflict & $769(18 \%)$ \\
\hline conflict of private life & $768(18 \%)$ \\
\hline moral conflict & $578(14 \%)$ \\
\hline political conflict & $391(9 \%)$ \\
\hline workplace conflict & $385(9 \%)$ \\
\hline crime conflict & $306(7 \%)$ \\
\hline conflict of fake identity & $277(7 \%)$ \\
\hline generational conflict & $228(5 \%)$ \\
\hline class conflict & $150(4 \%)$ \\
\hline racial/national conflict & $135(3 \%)$ \\
\hline gender conflict & $84(2 \%)$ \\
\hline sport/leisure conflict & $58(1 \%)$ \\
\hline conflict of religion & $37(1 \%)$ \\
\hline total number of conflicts & $\mathbf{4 1 6 6 ( 1 0 0 \% )}$ \\
\hline
\end{tabular}

Each film was characterized by at least one type of conflict, but typically two to three conflicts were aligned with each film. The two most common conflicts in Hungarian films are love conflict and conflict of private life [Fig. 3]. As mentioned before, we defined conflict of private life as anything that goes beyond a love affair, so the two categories have different focuses, and although there is, or may be, an overlap between them, they essentially complement each other. There is a love conflict in more than half of the Hungarian films, which is the same proportion as the conflict of private life. The conflict with the next highest count is moral conflict, which is typical of more than a third of the films. This means that half of all the conflicts found in Hungarian films are covered by these three types. Approximately a quarter of Hungarian films have political conflict, and there is a similar proportion of workplace conflict in the films.

However, as aggregate numbers carry only a limited message on their own, it is worth considering the distribution of conflicts over time as well. The following graph shows the percentage of films represented by each conflict type, in the three 
major periods (1931-1944, 1945-1989, 1990-2015). Certain types of conflict are found in the same proportions of the films in all three periods, while other types are much more characteristic of certain periods [Fig. 4 shows the occurrence of conflict type by period]. Private, moral, and workplace conflicts are present in the films in similar proportions in all three major periods. However, the pre-1945 era can be characterized by a massive number of love conflicts, and also a significant number of conflicts of fake identity. Specifically, 92 percent of the films have a love conflict and 44 percent have a conflict of fake identity. Films made during the socialist period have the highest rates of political conflicts (one in every three films), and the lowest rates of love and crime conflicts. In post-1989 films, the high rate of crime and generational conflicts are both noteworthy, although in this period, compared to the previous two, there are fewer outlying conflicts.

These distributions confirm the tendencies and basic hypotheses that are generally applied to Hungarian film history. Based on this, the period before 1945 can be characterized by romantic and private stories - the topic of uncertain identity also being particularly important. All this is clearly in line with the common thesis that the two leading genres of the era are comedy and melodrama (Balogh 2000; Vajdovich 2014).

The high rate of political conflicts in relation to films made during the years of socialism is also not surprising. There is an interesting feature - which is not in contradiction to any of our preliminary expectations, but rather has not been considered thus far - that the rate of love conflicts in this period is quite low. All this, of course, coincides with the general impression that in the period of socialism it was not private life but public and community themes that were in focus, and this trend is reflected with these changes in conflict types.

Finally, the period after 1989 is conspicuous in that it does not have, at first glance, any particularly conspicuous characteristics. An initial hypothetical explanation for this is that this period is characterized by heteronomous and diverse effects, and is in many ways a kind of complex mix of the prior two eras. Earlier in this article, the different perspectives on the close relationship between politics and film in Hungary and Eastern Europe were discussed. On the one hand, political changes strongly and decisively influenced the periodization of film history in the region, and on the other, politically motivated art/auteur films were important, due to their international (Western) critical and festival profile, at drawing attention to the Eastern European region during the era of socialism - especially from the 1960s to the change of regime. Therefore, we do not need to expand too much on the importance of politics. However, the role of, and changes in political conflicts 
are worth examining - across the history of Hungarian sound film. In the following, I will examine the deeper dynamics and the evolution of political conflicts with a more detailed analysis of their temporal variation and their relationship to genres.

\section{Political Conflicts in Hungarian Film History}

By political conflicts we mean what is related to public affairs, or, to put it differently and in a more general way, those events that can have an impact on society, or larger groups in the community. In this sense political conflicts are disputes, contentions or actions that are linked to power relations, or to the exercise of power. Thus, we coded as political conflict the activities and motifs that were directly connected to the values and organization of society, as well as discussions of these values. Political conflicts might take place between individuals or groups of people, between an individual and an institution, or between an individual or a group and an ideology. With this in mind, we can now examine the distribution of political conflicts in Hungarian films. The blue graph in the following figure shows the total number of films made each year, and the green graph shows the number of films which contained political conflict.

As discussed earlier, political conflict is one of the more common types of conflict, though not the most common one. We found political conflicts in a quarter of Hungarian films (391 out of 1514) [Fig. 5]. However, as we have already seen, the three major periods differ dramatically in terms of the occurrence of political conflict in the films. While we found political conflict in 12 percent of films made between 1931 and 1944, and in 21 percent of films made after 1989, more than a third, 36 percent of films made during the socialist period contained political conflict.

However, it is also worth noting that in the pre-1945 period, the graph shows a steady increase in the proportion of films with political conflict. Of course, this trend is also reflected in academic literature discussing Hungarian and Eastern European cinema, which has highlighted the strengthening of political content (and political, ideological control) since the late 1930s (Sándor 1997; Frey 2018; Gergely 2017). It is also clear how, in terms of the number of years of the socialist realist era, its low film output was caused by political content and conflict (Szilágyi 1997; Pólik 2019). However, from the mid-1950s onwards, the proportion of films containing political conflict appears to be broadly unchanged (but is, however, quite high in number), relative to the number of films made annually. It should be noted that political conflicts did not disappear from Hungarian films after 1989, in fact, this theme is almost as common in the post-socialist period as in the years before the change of regime. 
It might be helpful if we interrogate the data using an alternative visualization - by framing it in percentage terms. The graph in Figure 6 shows that there was a steady rise in the number of films containing political conflict since the late 1930s - but in this period the annual number of films also rose significantly. During the wartime years the number of films containing political conflict was around one-fifth of the films made each year. By comparison, in the Stalinist era - around 1950 - four out of five Hungarian films depicted political conflict. After that, until the change of regime, one-third of the films included some kind of political conflict, although with large annual fluctuations across the timeline (such as there being a peak year in 1970). Furthermore, it is worth noting that the proportion of political conflicts did significantly increase in the years before the change of regime, in the second half of the 1980s. Half of the films were politically charged during this period. However, in a very short time after the political change, the number of films containing political conflict dropped to ten percent in a few years, before returning to between ten and thirty percent - but still fluctuating massively. As there are wild fluctuations in the numbers across the whole timeline, we can examine the data after it has been smoothed, as shown in Figure 7. The trendline is much clearer here: we have a peak at the beginning of the 1950s, then there is a slow decrease till 1964 (the beginning of the so-called consolidation of the Kádár-regime). It is followed by growth up until the late 1960s and early 1970s, where the numbers remain high for a couple of years. A decrease starts in the mid-1970s and lasts until the early 1980s - where growth then begins, up until the political changes. After 1988 there is a constant decrease. Thus, we have three distinct peaks: 1951-1952, 1969-1970, and 1986-1988 - which are all relatively easy to explain (taking account of the filmmaking lead time, i.e. the length of time it takes to make the films). Each peak is related to some easily-identifiable political event or period. The first peak is in 1951-52: this is the era of Stalinism in Hungary, which was marked by years of planned cultural production and socialist realist films, when direct political-ideological interest led to the production of a vast number of films dealing with explicit political conflict. The next significant period is the ascent to the 1970 peak, which begins in 1968. In this year, the number of Hungarian films containing political conflict jumps. This boom can again be directly linked to the reform period around 1968 - and the still high number of politicallycharged films in the aftermath of (with reflections on) 1968. The third peak is between 1986 and 1988. It is not exactly the year of the regime change itself, 1989 (which is when the sharp decline begins), but the period before it. This peak can be linked to the weakening of censorship and the increase of filmmaking autonomy: to the growing possibilities of free speech about recent traumas (1956 revolution, Stalinism, 
Holocaust) and the political-social difficulties of the present. However, the insight lies somewhere else. Not in the high values, but in the low ones. A new research question might be: why the role of political conflicts is declining in the second half of the 1970s? Additionally, what other changes were characteristic of this period? The changes that took place in that era are also shown in another graph, where we see the distribution of class conflicts. Figure 8 shows even more clearly the backdrop of social and political forces than the previous one. In this graph the interesting thing again is not necessary where we see the highest occurrences of class conflict in Hungarian film history (i.e. during the war, in the 1950s, in the 1960s, and - which is something of a revelation - in the 2000s) but where it is absent.

From the mid-1950s to the first half of the 1970s, political conflicts were present in Hungarian films together with (or, often, but not necessarily, in the form of) class conflicts. From the mid-1970s until the end of the socialist years, there are essentially no class conflicts in Hungarian films. As we have seen, from the mid1980s onwards, the occurrence of political conflict increased significantly. However, class conflicts do not follow this trend. In other words, in that time (for an almost 20-year time span) political conflicts were presented in stories of a different nature. Here, then, a question arises: how can it be explained that the late Kádár-era was an island of class harmony in Hungarian films? Why are there no class conflicts, and what is in their place? I.e. what other conflicts characterize that period? To find explanations, we can check other queries in the database for insight and look at what other indicators have notable changes during this period. And hence we find such an indicator: in the second half of the 1970s political conflicts usually appear in stories that do not take place in the present time. The eras represented are varied, so this is not just the trend that has been widely discussed in Hungarian film criticism, whereby the number of films dealing with Stalinism and the 1956 revolution systematically increased in the late 1970s (Gelencsér 2002; Murai 2008), as the interwar period (A Strange Role [Herkulesfürdöi emlék, Pál Sándor, 1976]), the postwar years (Angi Vera [Pál Gábor, 1978], My Father's Happy Years [Apám néhány boldog éve, Sándor Simó, 1977]) and the nineteenth century (800 Hussars [80 huszár, Sándor Sára, 1978], Dead or Alive [Élve vagy halva, Tamás Rényi, 1979]) are also represented here in a meaningful way. Thus, the change in the inner dynamics and types of political conflicts seems to reveal a parallel decline in the number of class conflicts and present-day topics, which can be interpreted as a move away from direct criticism of everyday life.

However, the Hungarian films of the 1970s are not only characterized by a parallel decline in political and class conflicts. It is revealing to see that the percentage of 
each type of conflicts decreases during this period and begins to rise at the end of the decade [Fig. 9]. So how can this change be explained, and how does it affect the way Hungarian films look like in general? We know from previous graphs that the 1970s has another important feature: an increase in the proportion of auteur films. The question is whether these two trends are independent and parallel, or somehow related: i.e. can both be traced back to a common cause, or is one a function of the other? Does an increase in the proportion of auteur films cause a decrease in the number of conflicts in the films? Do auteur films have a narrower range of conflicts?

31 percent of Hungarian films are coded as auteur films, and of the total count of occurrences of conflict across the corpus, 26 percent can be found in auteur films. So, on average they have a narrower range of conflicts within them versus genre films - but obviously this does not imply that they are any weaker in conflict. ${ }^{4}$ In the next decade, in the 1980s, when the proportion of auteur films was also high (and even slightly higher), the number of conflicts was larger. Yet, the graph neatly shows that the different variety and broader range of conflicts in the 1980s can be attributed to the increase in the number of political and, especially, private conflicts in that decade. Moral conflicts define the 1960s and conflicts of private life define the 1980s. Political conflicts are important in both periods. However, there are no particularly prominent types of conflict in the 1970s, which also contributes to the narrower range of conflicts in that decade. In this case, can we attribute some common exogenous or endogenous reason to the trends? Does this narrowing range of conflicts in the 1970s stem from an era that is grey, neutral and characterless? Would this be the much-mentioned stagnation period, the dullest decade of socialism? In accordance with existing literature, our preliminary hypothesis would be that Hungarian filmmaking culture of the decade was shaped by the following important influences (moving from the political influences to the more internal, endogenous factors): the slowdown in reforms, the already mentioned socio-economic stagnation, the declining political influence of filmmaking, the sharp decline of attendance numbers (as well as a generational change), and the disappearance of the masters of popular cinema (Márton Keleti, Viktor Gertler, Frigyes Bán: filmmakers who began their career in the commercial filmmaking culture of the interwar period). All of this has so far been associated with the dominance of auteur films. We must now take the important next step of relating all these factors to the changes in conflict types, and other patterns of the films in this era.

4 Some types of conflict are more typical of auteur films (generational, political, private, and racial), and some are less characteristic (mainly fake identity and love - where there is a significant downward deviation from the average). 


\section{Genres and Political Conflicts}

As we have seen, the changes in the political conflict numbers can reveal much about the filmmaking culture of certain periods. To understand this more, we need to relate the different queries and patterns to each other. In the following, final section of the article, we return to the subject of genres and examine the relationship between political conflicts and genre patterns in Hungarian film history. Figure 10 shows the genre segmentation of the films containing political conflict. If we look at the distribution of films that contain political conflict by genre, we see that different genres are associated with political conflicts in different periods of Hungarian film history. Melodrama in the early 1940s, socialist realist production film ${ }^{5}$ in the early 1950s, comedy in the 1960s, auteur film in the 1970s and 1980s, and varied genre patterns in the years after the change of regime. The presence of politics endures throughout the timeline (which, as has already been said, is not at all surprising), but it varies from era to era in terms of the genre and the kind of story that the political conflict appears in.

In the 1940s, melodrama, which was a common and characteristic genre of the era, was the primary bearer of political conflict. In these films, political conflict is often linked to national confrontation - especially in the case of stories which take place in Transylvania, displaying the topic of Romanian-Hungarian ethnic conflicts (Bence Uz [Jenő Csepreghy, 1938], Silenced Bells [Elnémult harangok, László Kalmár, 1940]). Melodramas which had wartime settings were another significant vehicle for political conflict in this period. In the early 1950s, socialist realist films contained explicit political content - with their narratives focusing on sabotage actions against the Soviet Block (Underground Colony [Gyarmat a föld alatt, 1951], Full Steam, Ahead! [Teljes gózzel!, Félix Máriássy, 1951]). In the 1960s and 1970s, comedy, and within that, satire was the most consistent vehicle for political content and the grotesque presentation of the everyday life of socialism (János Dömölky's The Sword [A kard, 1976], Márton Keleti's The Corporal and the Others [A tizedes meg a többiek, 1965], or Péter Bacsó’s The Witness [A tanú, 1969]). However, from the late 1970s, auteur films were a major bearer of political content, such as László Vitézy's Peacetime [Békeidó, 1979] and Red Earth [Vörös föld, 1982] and Gyula Gazdag's Lost Illusions [Elveszett ilúziók, 1982]. With all this in mind, it is particularly interesting to see that in the post-socialist period, after 1989, we cannot find a privileged genre that, in terms of proportion, would most often carry political

$5 \quad$ We use the term production film for the socialist realist films which focus on the topic of factory production work and kolkhoz labour, thereby portraying the building of socialism. 
conflicts. Instead, we see a diverse genre distribution, i.e. political conflicts appear in different genres - be it auteur film (The Lord's Lantern in Budapest [Nekem lámpást adott kezembe az Úr Pesten, Miklós Jancsó, 1998]), drama (Sunshine [A Napfény íze, István Szabó, 2000]), comedy (Witness Again [Megint tanú, Péter Bacsó, 1994]), melodrama (Salmons of St. Lawrence River [A Szent Lörinc folyó lazacai, Ferenc András, 2002]), crime film (The Way You Are [Így ahogy vagytok, Károly Makk, 2010]) or historical film (Children of Glory [Szabadság, szerelem, Krisztina Goda, 2006]).

The decrease in the number and the role of political conflicts in Hungarian auteur films is clearly shown in Figure 11. Compared to the peak in the early 1970s, the number of auteur films with political conflicts is steadily and gradually declining. It is especially striking that in the years following the change of regime this type of conflict almost disappears from Hungarian auteur films - to then rise again in the 2000s. If we examine the temporal change and pattern of other genres with respect to political conflicts, we get additional informative results. In the case of comedies [Fig. 12], there are three major points of intensification of political conflicts: the early 1940s, the years after 1968, and the period from the first half of the 1990s to the early 2000s. Again, these periods can be characterized by typical (political) comedy variants. The comedies of the wartime years are typically placed in a historical milieu, and are often associated with operetta schemes (Gül Baba [Kálmán Nádasdy, 1940], Prince Bob [Bob herceg, László Kalmár, 1941]). ${ }^{6}$ At the turn of the decade in the 1960s and 1970s, the satires mentioned before (The Witness) are prominent. And finally, in the 1990s comedies mobilizing post-socialist nostalgia are typical (Dollybirds [Csinibaba, Péter Tímár, 1997], We Never Die [Sose halunk meg, Róbert Koltai, 1993]). If we look at crime movies instead of comedies, we get the same three points of intensification as we saw with comedies [Fig. 13]. However, in the case of crime movies we are dealing with a smaller number of productions (because they are a less common genre). There are crime films that include political conflict in the early 1940s (Machita [Endre Rodriguez, 1943]), then in the late 1960s and in the subsequent few years (The Mummy Interferes [A múmia közbeszól, Gábor Oláh, 1967], I’ve Become a Cop [Hekus lettem, Tamás Fejér, 1972]). But in the more than thirty years between 1978 and 2010, for example, we find a total of only three such films. With this in mind, it is particularly interesting that the increase in crime

6 It is also important that in the period considered the first golden age of Hungarian comedy, in the years between 1931 and 1938, we do not find any comedy that would have included a strong political conflict. Nevertheless, this can also be attributed to the fact that political conflicts appeared in the films of that period in a covert, latent way (but in a consistent and large number), as stated, for example, by Gábor Gergely in his book (Gergely 2018). 
films (and series) everywhere in the region in the 2010s (including Czech, Polish or Romanian films and series [Varga 2018]) is an important trend in Hungarian cinema as well - and accompanied with a growing number of political conflicts within them ( $X$ - The eXploited [ $X-A$ rendszerból törölve, Károly Ujj Mészáros, 2018]).

However, it is important to note that in terms of the proportion of films with political conflict, auteur and historical films have the highest numbers. Auteur films lead (more than 140), historical films are next (nearly 100), comedy and drama have far fewer (both around 40), and crime and melodrama films have even fewer cases than that.

On the one hand, the massive number of historical films in the group of Hungarian films dealing with political conflict is not surprising [Fig. 14], as it supports the statement expressed in literature that Hungarian (and Eastern European) films were strongly political (Dobreva 2012). Or that the works of the region and of Hungarian filmmaking culture have used history as a device, primarily to depict political conflicts (and often to create an allegory or parable about the present). This is also supported by the fact that the number of historical films dealing with political conflict increased in the 1950s (while the early 1940s already had precursors to this trend [Varga 2017]) and such films were present in high numbers until the end of the Socialist era. Historical films with political conflict did not disappear after 1989: although their number is decreasing, they are sometimes bolstered by an external institutional factor - such as the aforementioned wave of films made on the 50th anniversary of the 1956 revolution (around which the graph also shows a large increase). On the other hand, it should also be emphasized that almost $80 \%$ of the works belonging to the group of Hungarian historical films have a political conflict, therefore politics is one of the most important aspects of Hungarian historical films (but also of the genre in general).

In terms of the relationship between political conflict and genre, it is worth mentioning another, final case: melodrama [Figure 15]. Looking at the distribution of this genre, we see that while melodramas are present throughout Hungarian film history, melodramas containing political conflict are almost completely the preserve of one era, namely the most prevalent period of the genre, the early 1940s. In this respect, we can say that while historical films are one of the most characteristic carriers and portrayers of political conflicts in Hungarian film history, in the case of melodrama, the concurrence of political conflict and melodramatic narrative is not typical - and can only be seen in an era where melodramas are made in a uniquely large number anyway. 


\section{Conclusions}

One of our initial claims was that the trends and changes of Eastern European filmmaking cultures were decisively influenced by politics, and that especially in the years of socialism, the international attraction and appeal of films from the region was driven directly by political curiosity. Examining the conflict types of Hungarian films, this article inquired as to what other long-term trends might characterize Hungarian filmmaking culture - beside the two key turning points $(1945,1989)$ and beyond the duality of and the division between genre and auteur/ art films. We have found that the two most common conflict types in Hungarian films are love conflict and conflict of private life, followed by moral conflicts. Both love conflicts and conflicts of private life can be found in half of all Hungarian films (these conflicts usually complement each other), and moral conflicts are typical of more than a third of the films. While political aspects play a prominent role in the discussion of Hungarian films, it is important to note that political conflicts are only the fourth most common type in Hungarian film history (with almost the same count as workplace conflicts). With respect to the political turning points and the periodization of Hungarian film history, we have found that each of the three broad periods is characterized by its own distinctive set of prominent conflict types. The pre-1945 era is characterized by a massive number of love conflicts, the socialist period by the highest rate of political conflicts (and the lowest rates of love and crime conflicts), and the post-socialist period by a high rate of crime and generational conflicts. The examination of conflicts has also yielded results in terms of rethinking our understanding of genre and auteur/art films. We have found that by analysing the connections between conflict types and genres, we can see several recurring patterns that have received little attention thus far. One of the most astonishing of these is the status and trends of the 1970s: the range of conflicts narrowed considerably over the decade, especially in the middle of the 1970s. The parallel trend of the dominance of auteur films in that decade goes some way to providing an explanation for that, as Hungarian auteur films have a narrower range of conflicts compared to genre films. Furthermore, we found that while moral and political conflicts define the 1960s, and conflicts of private life and political conflicts define the 1980s, there are no particularly prominent types of conflict in the 1970s, which might also contribute to the narrower range of conflicts in the decade. This concurrence of trends (the dominance of auteur films and the narrowing of the range of conflicts in the films of the 1970s) suggests a combination of cinematic, cultural, and political influences, and calls attention to the importance of further investigation. 


\section{References}

Adamczak, Marcin. 2012. Polish Cinema after 1989. A Quest for Visibility and a Voice in the Market. Iluminace vol. 31, no. 4: 45-59.

Allen, Jessica, Sonia Livingstone and Robert Reiner. 1998. True Lies: Changing Images of Crime in British Postwar Cinema. European Journal of Communication vol. 13, no. 1: 53-75.

Andrews, David. 2013. Theorizing Art Cinemas: Foreign, Cult, Avant-Garde, and Beyond. Austin: University of Texas Press.

Balogh, Gyöngyi. 2000. History of the Hungarian Film, from the Beginning until 1945. Filmkultúra https://filmkultura.hu/regi/2000/articles/essays/balogh. en.html. Last accessed 04. 07. 2020.

Balogh, Gyöngyi and Király Jenő. 2000. "Csak egy nap a világ...” A magyar film múfaj-és stílustörténete 1929-1936 [“The World is But a Day...” A History of Hungarian Film Genres and Styles 1929-36]. Budapest: Magyar Filmintézet.

Balogh, Gyöngyi, Gyürey Vera and Honffy Pál. 2004. A magyar játékfilm története a kezdetektól 1990-ig [A History of Hungarian Film from the Beginnings until 1990]. Budapest: Múszaki Könyvkiadó.

Beumers, Birgit and Eugenie Zvonkine. 2018. Ruptures and Continuities in Soviet/ Russian Cinema. Styles, Characters and Genres Before and After the Collapse of the USSR. London and New York: Routledge.

Bordwell, David. 1979. The Art Cinema as a Mode of Film Practice. Film Criticism vol. 4, no. 1: 56-64.

Bordwell, David. 1989. Historical Poetics of Cinema. In The Cinematic Text, ed. R. Barton Palmer, 369-398. New York: AMS Press.

Bordwell, David. 1997. On the History of Film Style. Cambridge, Massachusetts and London, England: Harvard University Press.

Boyd, Danah and Kate Crawford. 2011. Six Provocations for Big Data. A paper presented at Oxford Internet Institute's “A Decade in Internet Time: Symposium on the Dynamics of the Internet and Society" on September 21, 2011. https:// papers.ssrn.com/sol3/papers.cfm?abstract_id=1926431. Last accessed 04. 07. 2020.

Brown, Marshall. 2001. Periods and Resistances. MLQ: Modern Language Quarterly vol. 62, no. 4: 309-316.

Burns, Bryan. 1996. World Cinema: Hungary. Madison, Teaneck: Fairleigh Dickinson University Press. 
Byg, Barton. 2002. Introduction: Reassessing DEFA Today. In East Germany: Past and Future of DEFA Film, ed. Barton Byg and Betheny Moore, 1-23. Washington, DC: AICGS.

Cunningham, John. 2004. Hungarian Cinema from Coffee House to Multiplex. London: Wallflower Press.

Dobreva, Nikolina. 2012. Eastern European Historical Epics: Genre Cinema and the Visualization of a Heroic National Past. In A Companion to Eastern European Cinemas, ed. Imre Anikó, 344-365. Malden, MA: Wiley-Blackwell.

Frey, David. 2018. Jews, Nazis and the Cinema of Hungary: The Tragedy of Success, 1929-44. London and New York: I.B. Tauris.

Galt, Rosalind and Karl Schoonover. 2010. Global Art Cinema: New Theories and Histories. Oxford, New York: Oxford University Press.

Garin, Martin and Albert Elduque. 2016. Quantitative Metaanalysis of Visual Motifs Throughout Film History. El profesional de la información vol. 25, no. 6: 883892.

Gelencsér, Gábor. 2017. Magyar film 1.0 [Hungarian Film 1.0]. Budapest: Holnap Kiadó.

Gelencsér, Gábor. 2002. A Titanic zenekara. Stílusok és irányzatok a hetvenes évek magyar filmmúvészetében [The Orchestra of the Titanic: Styles and Trends in the Hungarian Cinema of the Seventies]. Budapest: Osiris.

Gergely, Gábor. 2017. Hungarian Film, 1929-1947. National Identity, Anti-Semitism and Popular Cinema. Amsterdam: Amsterdam University Press.

Grieveson, Lee. 2004. Woof, Warp, History. Cinema Journal vol. 44, no. 1: 119-126. Hake, Sabine 2002. German National Cinema. New York: Routledge.

Haltof, Marek. 2018. Polish Cinema: A History. New York, Oxford: Berghahn Books. Hayot, Eric 2020. What Is the Time of Literature? American Literary History vol. 32, no. 1: 201-208.

Heftberger, Adelheid. 2019. Digital Humanities and Film Studies: Visualising Dziga Vertov's Work. Cham, Switzerland: Springer International Publishing.

Heiduschke, Sebastian. 2013. East German Cinema: DEFA and Film History. New York: Palgrave MacMillan.

Hendrykowska, Małgorzata. 1999. East Central Europe Before the Second War. In The Oxford History of World Cinema, ed. Geoffrey Nowell-Smith, 383-389. Oxford: Oxford University Press.

Johnson, Kevin B. 2012. Annexation Effects: Cultural Appropriation and the Politics of Place in Czech-German Films, 1930-1945. PhD Dissertation, 
University of Washington. https://digital.lib.washington.edu/researchworks/ handle/1773/22621. Last accessed 04. 07. 2020.

Klimeš, Ivan. 2007. A Dangerous Neighbourhood: German Cinema in the Czechoslovak Region, 1933-45. In Cinema and the Swastika. The International Expansion of Third Reich Cinema, ed. Roel Vande Winkeland and David Welch, 112-129. Hampshire and New York: Palgrave Macmillan.

Kovács, András Bálint. 2018. Múfajok a magyar filmtörténetben [Genres in Hungarian Film History]. Apertúra vol. 13, no. 3. http://uj.apertura.hu/2018/ tavasz/kab-mufajok-a-magyar-filmtortenetben/. Last accessed 04. 07. 2020.

Maltby, Richard, Daniel Biltereyst and Philippe Meers. 2011. Explorations in New Cinema History: Approaches and Case Studies. Malden, MA: Wiley-Blackwell. Mazlish, Bruce: 2011. Ruptures in History. Historically Speaking vol. 12, no. 3: 32-33.

Mišíková, Katarína. 2016. The Eternal Return of Slovak Cinema: Narrative Structures, Genre Codes and Cinematic Memory after 1989. In Cultural Studies Approaches in the Study of Eastern European Cinema: Spaces, Bodies, Memories, ed. Virginás Andrea, 245-267. Newcastle upon Tyne: Cambridge Scholars Publishing.

Moretti, Franco. 1998. Atlas of the European Novel 1800-1900. London and New York: Verso.

Moretti, Franco. 2013. Conjectures on World Literature. In Distant Reading, 43-62. London and New York: Verso.

Murai, András. 2008. Film és kollektív emlékezet: magyar múltfilmek a rendszerváltozás után [Film and Collective Memory: Hungarian Film about the Past after the Political Changes]. Szombathely: Savaria University Press.

Neale, Steve. 1981. Art Cinema as Institution. Screen vol. 22, no. 1: 11-40.

Pólik, József. 2014. Elveszett illúziók: a magyar politikai film korszakai [Lost Illusions: Eras of Hungarian Political Films]. In A hazugság. Lábjegyzetek Platónhoz [The Lie. Footnotes to Plato], ed. Laczkó Sándor, 173-193. Szeged: Pro Philosophia Szegediensi Alapítvány.

Rubinson, Claude and John Mueller. 2016. Whatever Happened to Drama? A Configurational-Comparative Analysis of Genre Trajectory in American Cinema, 1946-2013. The Sociological Quarterly vol. 57, no. 4: 597-627.

Salt, Barry 2006. Moving into Pictures: More on Film History, Style, and Analysis. London: Starword.

Sándor, Tibor. 1997. Örségváltás után. Zsidókérdés és filmpolitika 1938-1944 [After the Changing of the Guard: The Jewish Question and Film Policy 1938-1944]. Budapest: Magyar Filmintézet. 
Serlen, Rachel. 2010. The Distant Future? Reading Franco Moretti. Literature Compass vol. 7, no. 3: 214-225.

Szilágyi, Gábor. 1992. Túzkeresztség: a magyar játékfilm története, 1945-1953 [Baptism of Fire: The History of Hungarian Cinema 1945-1953]. Budapest: Magyar Filmintézet.

Szilágyi, Gábor. 1994. Életjel: A magyar filmmúvészet megszületése 1954-1956 [Sign of Life: The Birth of Hungarian Film Art 1954-1956]. Budapest: Magyar Filmintézet.

UK Film Council. 2006. Stories we tell ourselves. The Cultural Impact of UK Film 1946-2006. London: UK Film Council.

Varga, Balázs. 2012. Cooperation: the Organization of Studio Units in the Hungarian Film Industry of the 1950s and 1960s. In Restart Zespolow Filmowych. Film Units: Restart, ed. Martin Adamczak, Piotr Marecki and Marcin Malatynski, 313337. Kraków: Ha!art.

Varga, Balázs. 2016a. Filmrendszerváltások: A magyar játékfilm intézményeinek átalakulása 1990-2010 [Film Regime Changes: The Transformation of Hungarian Film Industry, 1990-2010]. Budapest: L’Harmattan Kiadó.

Varga, Balázs. 2016b. The Missing Middle. Trends and Genres in Hungarian Popular Cinema after the Political Changes. In Transformation Processes in Post-Socialist Screen Media, eds. Jana Dudková and Katarína Mišíková, 97-116. Bratislava: Academy of Performing Arts, Institute of Theatre and Film Research - The Slovak Academy of Sciences.

Varga, Balázs. 2017. Transformations: Hungarian Popular Cinema in the 1950s. In Popular Cinemas in Central Europe: Film Cultures and Histories, eds. Dorota Ostrowska, Francesco Pitassio and Varga Zsuzsanna, 85-101. New York: I.B. Tauris.

Varga, Balázs. 2018. Eastern Crime Wave and Its Social and Cultural Intersections. Contact Zones vol. 3, no. 1. http://contactzones.elte.hu/journal/20181-2. Last accessed 04. 07. 2020.

Voráč, Jiří. 1997. Czech Film After 1989. Kinema: a Journal for Film and Audiovisual Media vol. 5, no. 1. https://openjournals.uwaterloo.ca/index.php/kinema/ article/view/852/793. Last accessed 04. 07. 2020.

Votruba, Martin. 2005. Historical and National Background of Slovak Filmmaking. KinoKultura [Special Issue] no. 3: 1-18.

Vajdovich, Györgyi. 2014. Vígjátékváltozatok az 1931-1944 közötti magyar filmben [Variants of Comedies in Hungarian Cinema between 1931-1944]. Metropolis vol. 18, no. 3: 8-22. 
Záhonyi-Ábel, Márk. 2020. Filmcenzúra Magyarországon a Horthy-korszakban [Film Censorship in Hungary during the Horthy Era]. Unpublished PhD Dissertation, Budapest: ELTE University, Faculty of Humanities.

\section{List of Figures}

Figure 1. Main genres and auteur films in Hungarian film history.

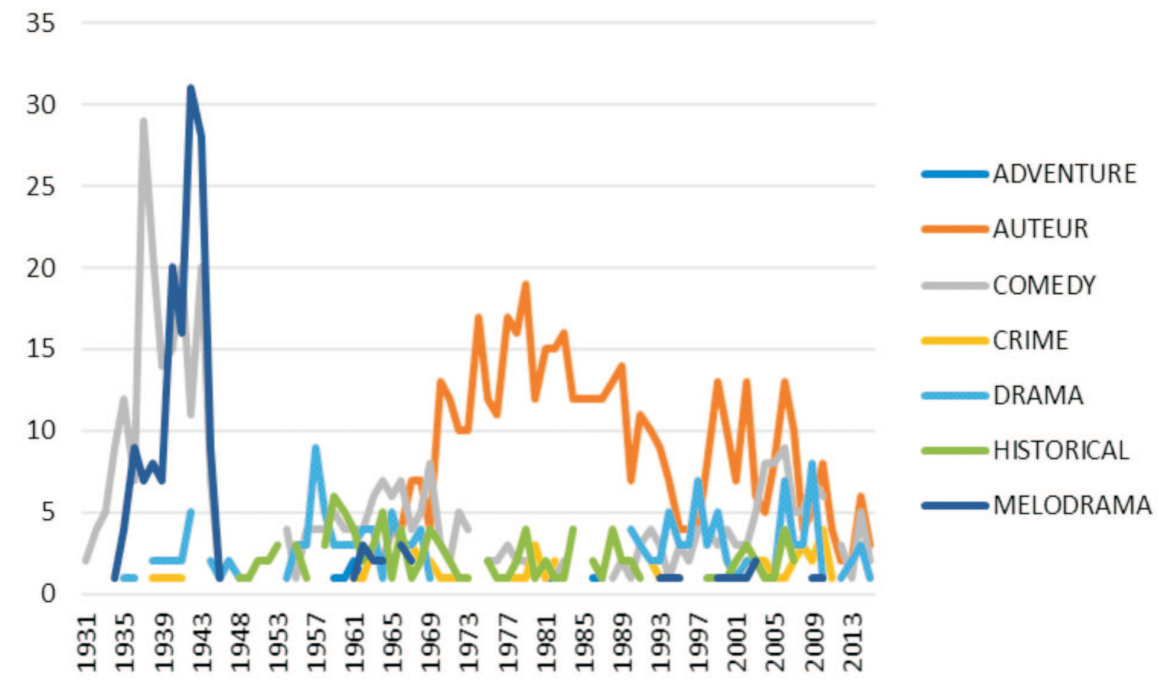

Figure 2. Hungarian film production, 1931-2015.

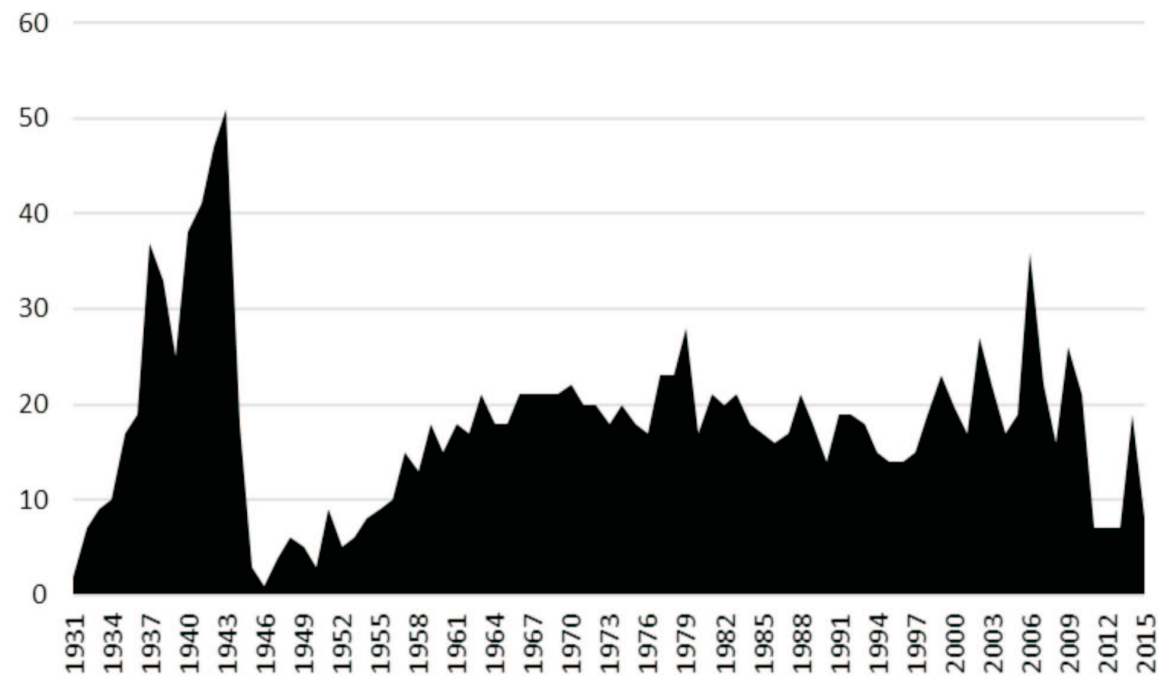


Figure 3. Conflict types in Hungarian film history.

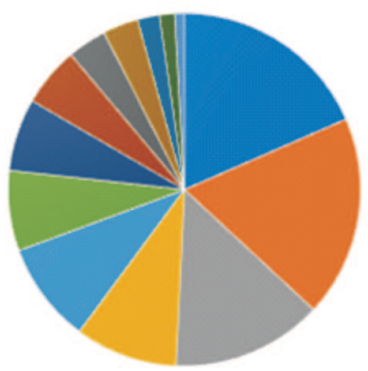

- love conflict

" political conflict

- conflict of fake identity

- racial-national conflict

" religious conflict
- private conflict

" workplace conflict

- generational conflict

- gender conflict
= moral conflict

- crime conflict

- class conflict

- sport/leisure conflict

Figure 4. Occurrence of conflict type by period (based on percentage of films containing each conflict type).

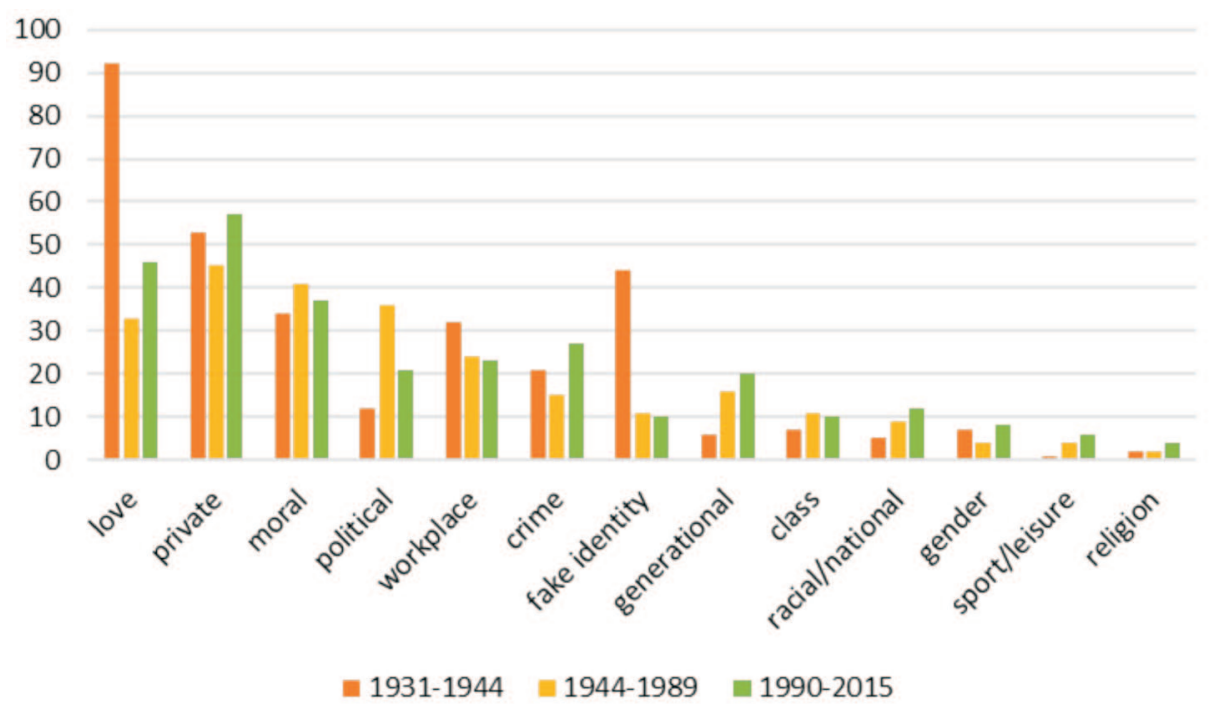


Figure 5. Political conflicts in Hungarian films.

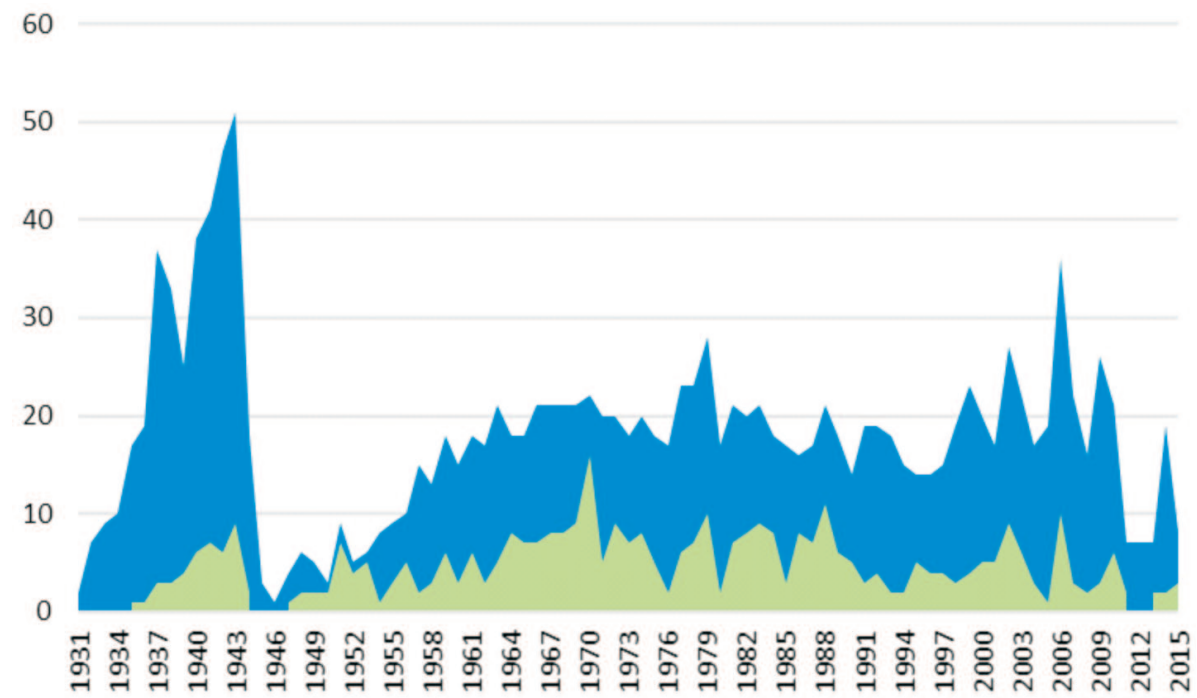

Figure 6. Political conflict as a percentage of films produced.

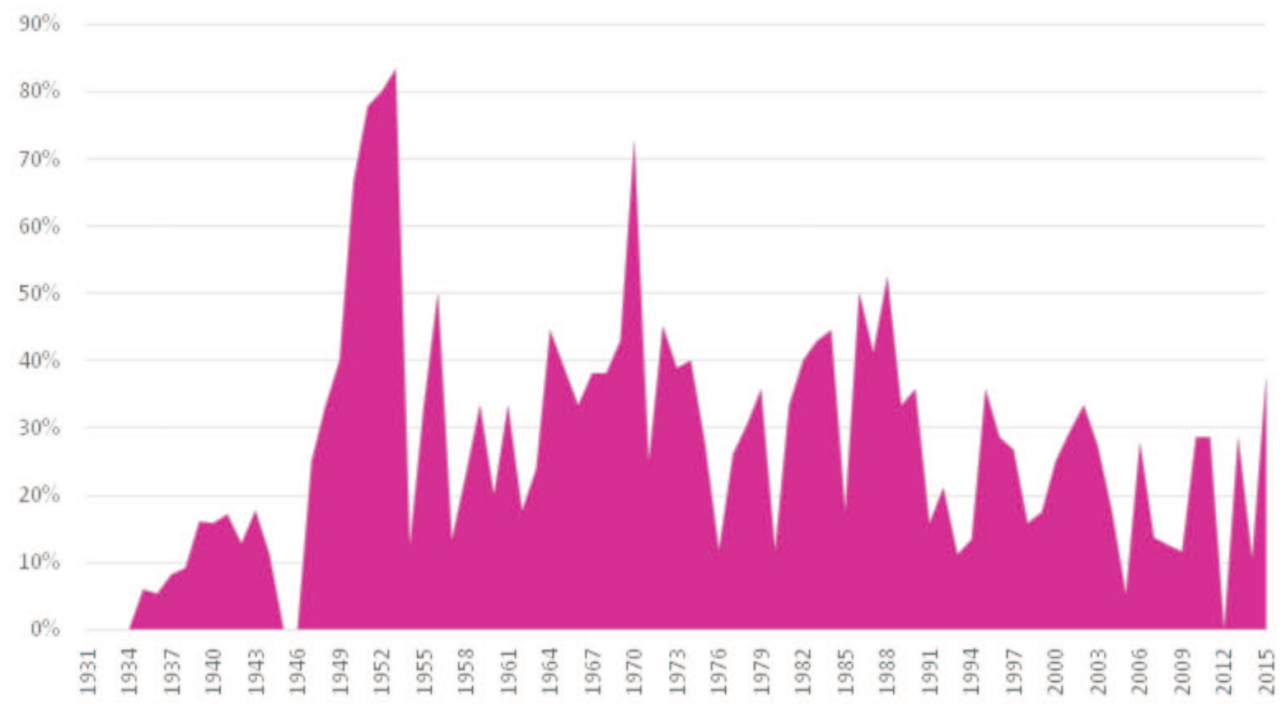


Figure 7. Political conflict with exponential smoothing (alpha 0.1).

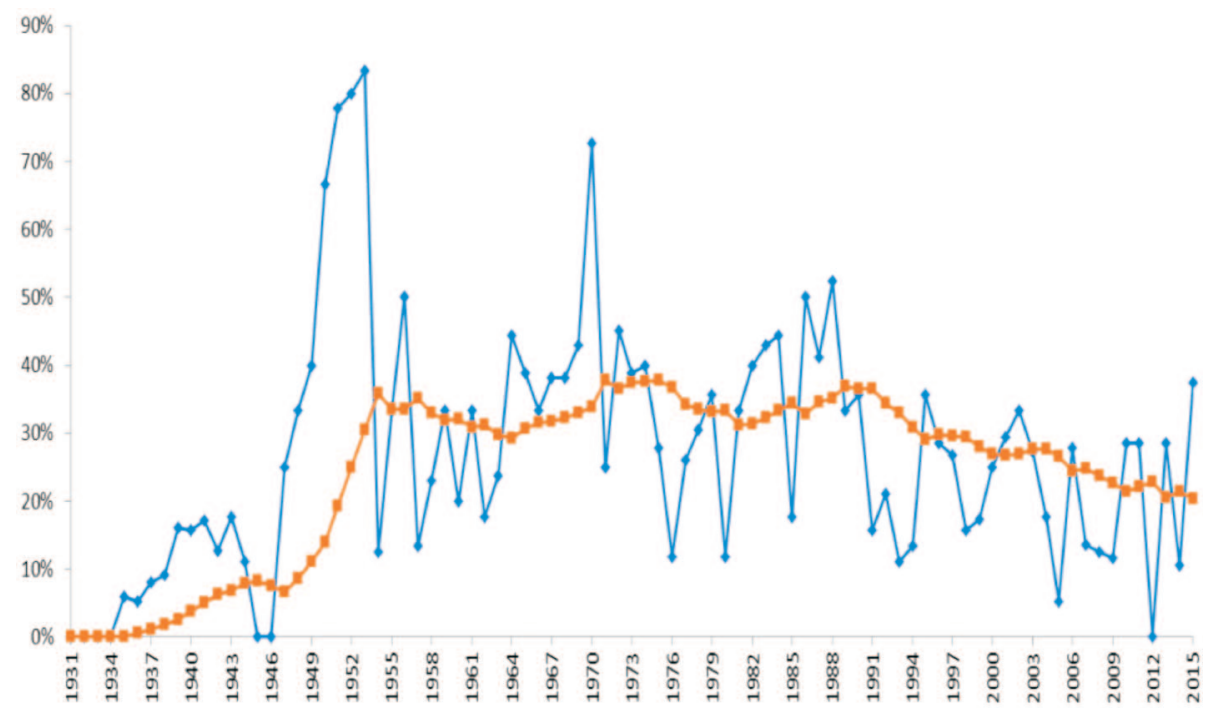

Figure 8. Class conflicts in Hungarian films.

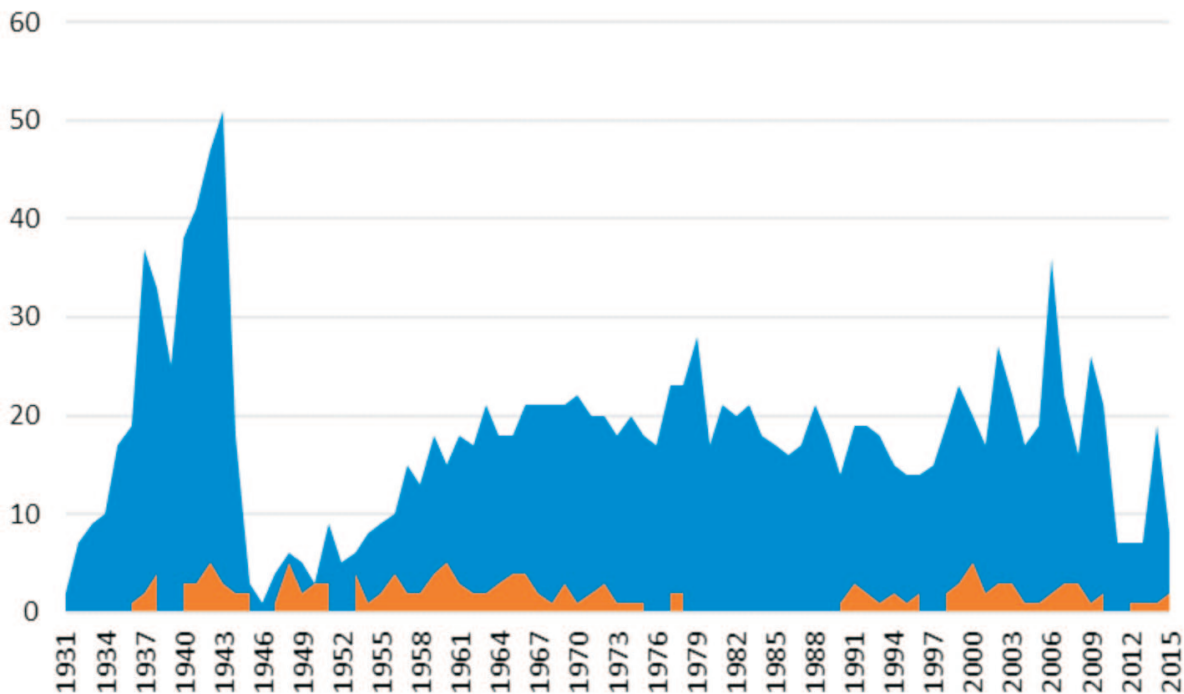


Figure 9. Conflict types in Hungarian 1960-1989 (in the percentage of the films produced).

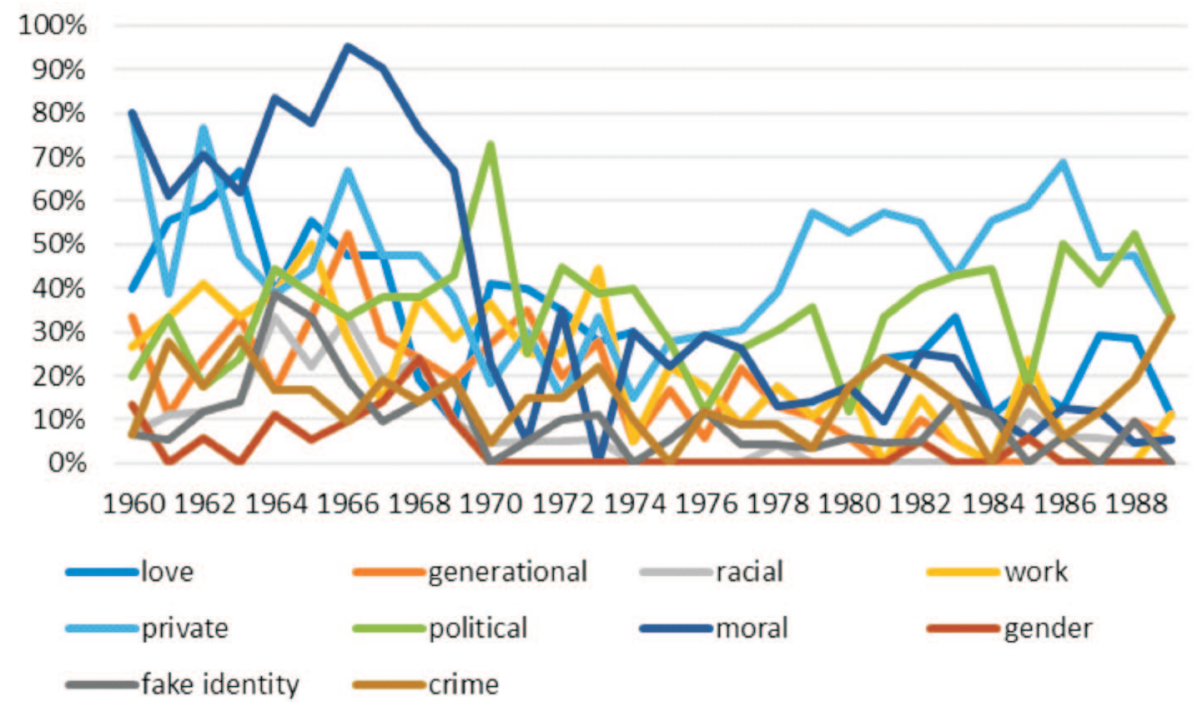

Figure 10. Films with political conflicts/main genres.

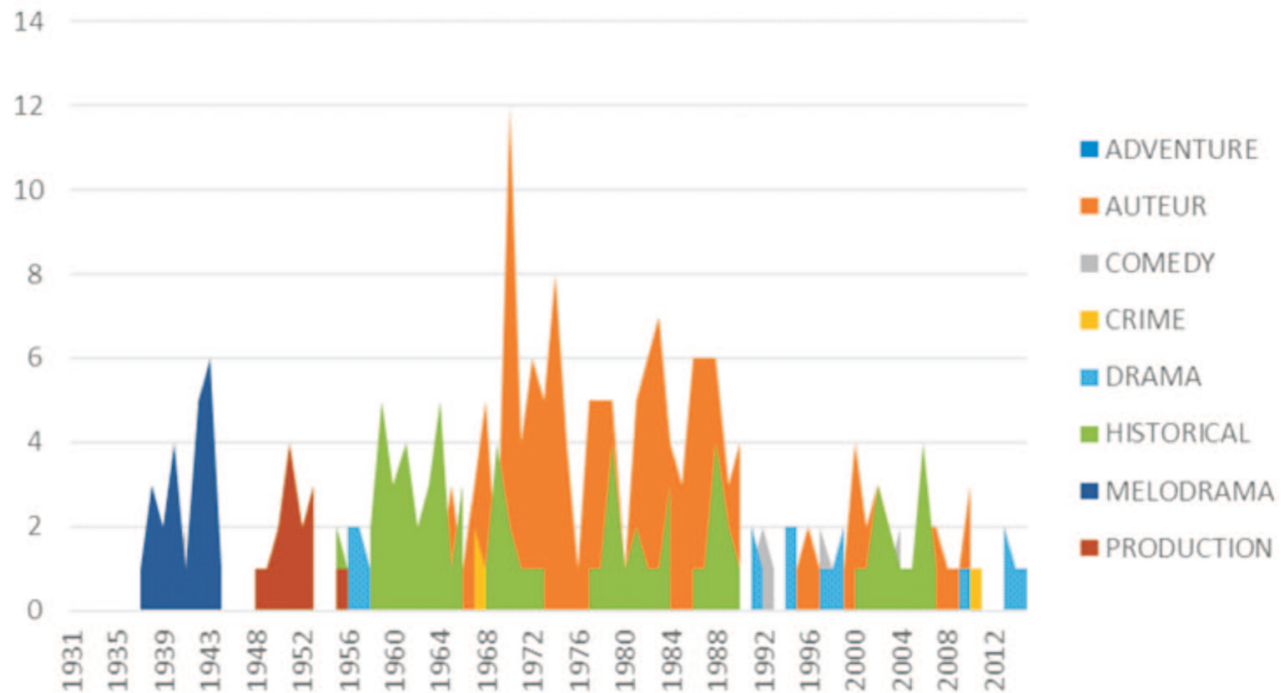


Figure 11. Auteur films with political conflict.

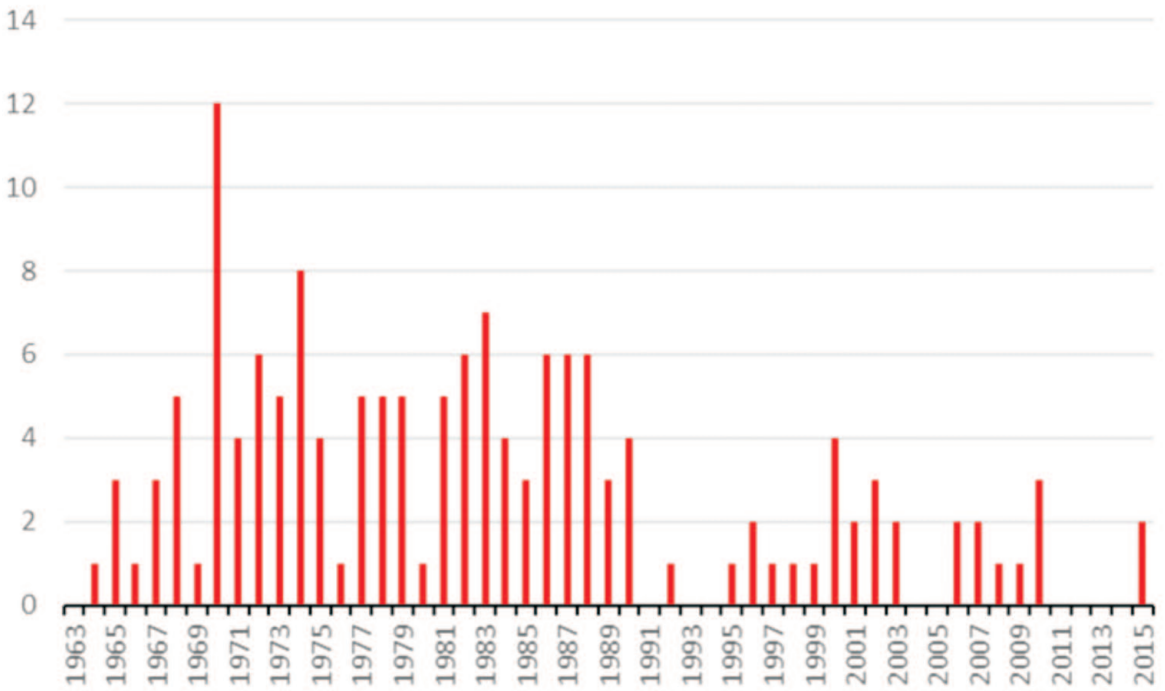

Figure 12. Comedies with political conflict.

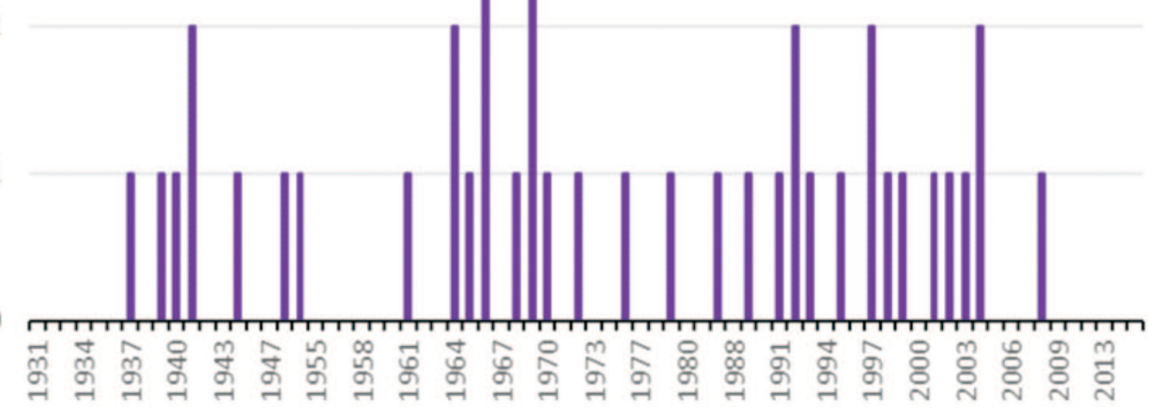


Figure 13. Crime films with political conflict.

3

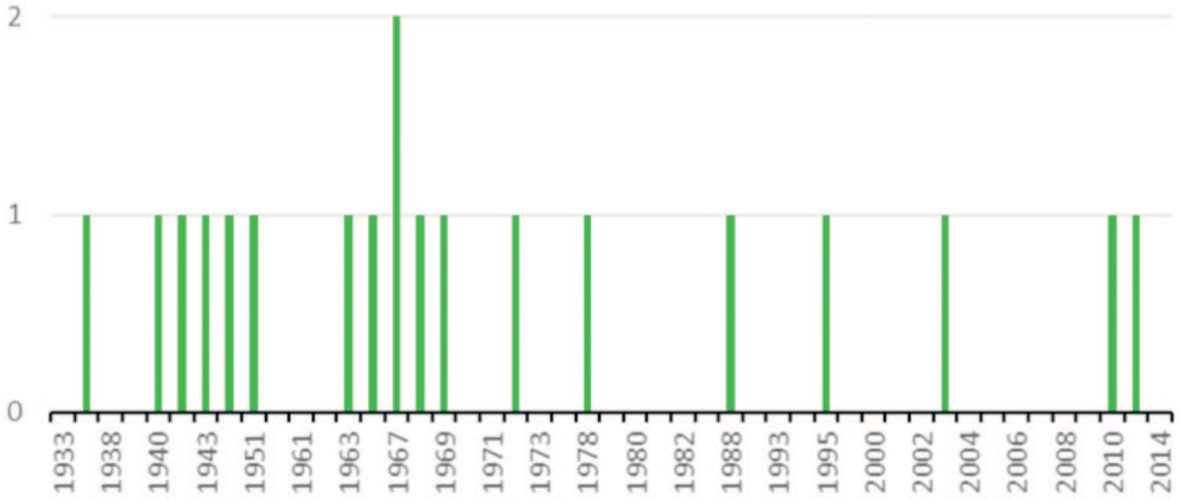

Figure 14. Historical films with political conflict.

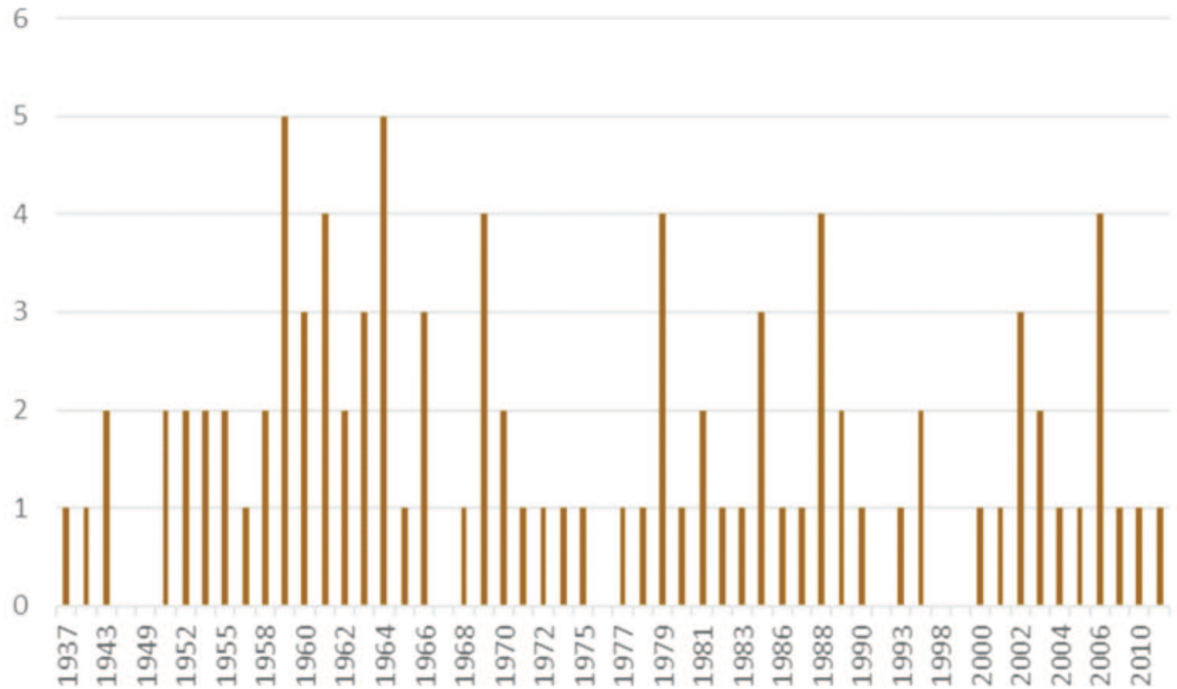


Figure 15. Melodramas with political conflict.

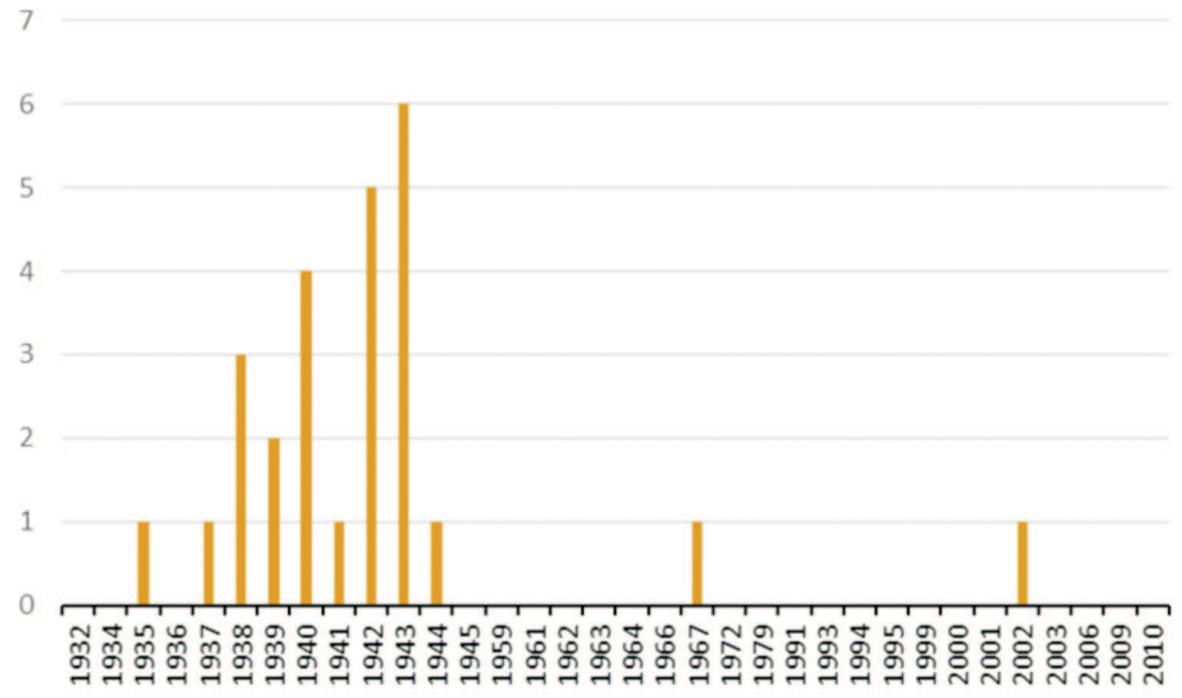

